\title{
ST
}

Science \& Technology

PAPER - OPEN ACCESS

\section{Konversi Oil Palm Frond (OPF) Sebagai Bahan Baku Bioetanol Dengan Proses Pretreatment Organosolv dan Hidrolisa Asam}

\author{
Author : Saisa Saisa dkk., \\ DOI $\quad: 10.32734 /$ st.v2i1.315 \\ Electronic ISSN $\quad: 2654-7082$ \\ Print ISSN : :2654-7074
}

Volume 2 Issue 1 - 2018 TALENTA Conference Series: Science \& Technology (ST)

This work is licensed under a Creative Commons Attribution-NoDerivatives 4.0 International License.

Published under licence by TALENTA Publisher, Universitas Sumatera Utara

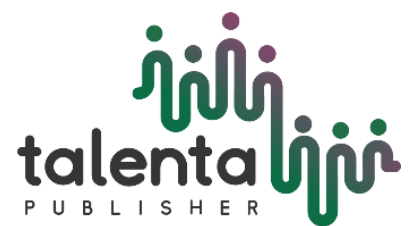




\title{
jibli

\section{Konversi Oil Palm Frond (OPF) Sebagai Bahan Baku Bioetanol Dengan Proses Pretreatment Organosolv dan Hidrolisa Asam}

\author{
Saisa $^{\mathrm{a}, \mathrm{b}^{*}}$, Husni Husin ${ }^{\mathrm{c}}$, Mahidin $^{\mathrm{c}}$ \\ ${ }^{a}$ Program Studi Teknik Kimia Fakultas Teknik Universitas Serambi Mekkah, Banda Aceh Indonesia \\ ${ }^{b}$ Mahasiswa Doktor Ilmu Kimia, Fakultas Matetatika dan Ilmu Pengetahuan Alam, Universitas Sumatera Utara, Medan Indonesia \\ 'Program Studi Teknik Kimia Fakultas Teknik Universitas Syiah Kuala, Banda Aceh Indonesia
}

${ }^{a}$ saisa@serambimekkah.ac.id

\begin{abstract}
Abstrak
Penelitian ini menggunakan pelepah sawit sebagai sumber holoselulosa yang dikonversi menjadi bahan baku bioetanol (gula total). Penelitian ini bertujuan untuk mempelajari proses pretreatment organosolv berpelarut etanol dan hidrolisa asam terhadap konversi pelapah sawit menjadi gula. Proses pembuatan gula dari pelepah sawit diawali dengan melakukan proses delignifikasi dan dilanjuti dengan proses hidrolisa. Proses delignifikasi berlangsung pada kondisi dengan variasi konsentrasi etanol 35\%, 55\%, 75\%, dan 90\% v/v temperatur 100 dan $120^{\circ} \mathrm{C}$ dan waktu reaksi 60 dan 90 menit. Selanjutnya untuk proses hidrolisa menggunakan asam sulfat dengan variasi konsentrasi $1 \%$, temperatur $60,70,80,90$ dan $100^{\circ} \mathrm{C}$ dan waktu reaksi 15, 30, 45, 60 dan 75 menit. Hasil penelitian menujukkan bahwa pada kondisi delignifikasi dengan konsentrasi $\mathrm{C}_{2} \mathrm{H}_{5} \mathrm{OH} \mathrm{75 \%}$, temperatur $120{ }^{\circ} \mathrm{C}$, selama 60 menit, serta $1 \%$ katalis $\left(\mathrm{H}_{2} \mathrm{SO}_{4}\right)$ dan pada kondisi hidrolisa $\mathrm{H}_{2} \mathrm{SO}_{4} 1 \%$, waktu 30 menit, dan temperatur $90{ }^{0} \mathrm{C}$ diperoleh yield total gula tertinggi sebesar $93,65 \mathrm{mg} / \mathrm{L}$.
\end{abstract}

Kata kunci: pelepah sawit, bahan lignoselulosa, delignifikasi, hidrolisis, feedstock bioethanol

\section{Pendahuluan}

Biomassa lignoselulosa terdapat pada jenis tanaman apapun, dan biasanya diperoleh dari limbah perkebunan atau pertanian. Oil palm frond (OPF) atau pelepah kelapa sawit merupakan salah satu jenis bahan lignoselulosa yang banyak dihasilkan dari suatu perkebunan kelapa sawit dan belum dimanfaatkan secara optimal apalagi sebagai bahan bakar alternatif. Dalam setiap hektarnya dapat dihasilkan berat kering pelepah sawit sebanyak $1.640 \mathrm{~kg}$ [1]. Pelepah sawit memiliki kandungan holoselulosa yang cukup tinggi yaitu 83,5\% dan pelepah sawit dapat dipanen 1-2 pelepah/ pohon sepanjang tahun bersamaan dengan panen tandan buah segar [2]. Hal ini menjadikan OPF berpotensi untuk diolah menjadi bioetanol.

Berbagai penelitian telah dilakukan dalam memproduksi bioetanol, baik itu dari bahan berpati, molasses, sari buah maupun dari biomassa lignoselulosa. Ishola [3] telah berhasil memproduksi 85\% etanol berbaku baku spruce chips (Sejenis pohon cemara dari hutan Swedia), selanjutnya Swain \& Krishnan [4] telah mengkonversi jerami padi menjadi bioetanol dengan menggunakan Candida Tropicalis sebagai media fermentasi dan menghasilkan yield hingga $98 \%$. Pada waktu yang sama pula Liu [5] telah memproduksi feedstock bioetanol dari ampas tebu yang dikenal dengan "bagass" dengan nilai konversi hingga 99,51\%. Namun produksi bioetanol dari OPF belum ada studi yang melakukanya, sehingga peneliti mencoba melakukan studi dengan mempelajari melalui pendekatan-pendekatan dengan komposisi material yang memiliki kemiripan.

OPF merupakan limbah perkebunan yang sangat jarang dimanfaatkan oleh masyarakat, terutama masyarakat Aceh yang tinggal disekitar perkebunan seperti di kawasan Barat Selatan Aceh, Langsa, Aceh Tamiang dan Kabupaten Aceh Utara yang merupakan sentra produksi kelapa sawit dengan luas lahan keseluruhan hingga 393.000 Ha [6]. OPF dalam penelitian ini direncanakan akan diperoleh dari kawasan perkebunan PT. Fajar Baizuri \& Brother dan PT. Scofindo di Kabupaten Nagan Raya, Propinsi Aceh. Bioetanol yang dihasilkan dan telah diuji dan dianalisa sesuai 
standar pemakaiannya dalam bahan tambahan dalam bahan bakar diharapkan dapat diaplikasikan langsung untuk mobilitas masyarakat di Kabupaten Nagan Raya [7].

Pada penelitian ini akan dilakukan proses pretreatment dan hidrolisa terhadap bahan baku (pelepah sawit). Proses pretreatment melibatkan proses fisik (physical pretreatment) dan proses kimia (chemical pretreatment) pada bahan baku (pelepah kelapa sawit). Pada proses ini akan dihasilkan holoselulosa dari pelepah sawit yang selanjutnya akan dihidrolisa. Proses hidrolisa holoselulosa (hasil dari pretreatment OPF) dilakukan dengan menggunakan asam sulfat encer $\left(\mathrm{H}_{2} \mathrm{SO}_{4}\right)$ yang akan menghasilkan glukosa dan gula-gula sederhana lainnya (sebagai feedstock bioetanol) dan selanjutnya akan difermentasi untuk menghasilkan bioetanol.

\section{Metode Penelitian}

Limbah lignoselulosa merupakan bahan baku generasi kedua dalam produksi bioetanol. Oil Palm Frond (OPF) adalah limbah biomassa yang dihasilkan dari perkebunan kelapa sawit, yang diperoleh dari Kabupaten Nagan Raya. Kegiatan penelitian dilakukan di Laboratorium Teknik Kimia Universitas Syiah Kuala dan Laboratorium Teknik Kimia Universitas Serambi Mekkah.

\subsection{Alat dan Bahan}

Alat-alat yang digunakan pada penelitian ini adalah peralatan-peralatan gelas, Termometer, Timbangan Analitik, Kertas saring, Pipet volume, $\mathrm{pH}$ Meter, $\mathrm{pH}$ indikator, Autoclave, shaker, incubator, screening, ball mill, Hot Plate, HPLC (Shimadzu), XRD (Shimadzu XRD 600 X-ray diffractometer), SEM (Scanning electron microcope) Philips XL-30 dan Oven.

Bahan-bahan yang digunakan pada penelitian ini adalah OPF, ekstrak yeast, $\left(\mathrm{NH}_{4}\right)_{2} \mathrm{SO}_{4}, \mathrm{MgSO}_{4} .7 \mathrm{H}_{2} \mathrm{O}, \mathrm{K}_{2} \mathrm{HPO}_{4}$, $\mathrm{CaCl}_{2}$. $2 \mathrm{H}_{2} \mathrm{O}$. aquadest, Etanol $\left(\mathrm{C}_{6} \mathrm{H}_{5} \mathrm{OH}\right)$, Glukosa $\left(\mathrm{C}_{6} \mathrm{H}_{12} \mathrm{O}_{6}\right)$, Natrium Hidroksida $(\mathrm{NaOH})$, enzim selulase, $\beta$ glukosidase, saccharomyces cerevisiae, Urea $\left(\mathrm{CO}\left(\mathrm{NH}_{2}\right)_{2}\right)$.

\subsection{Variabel Penelitian}

\subsubsection{Variabel Tetap}

a. Kondisi pengeringan $\mathrm{OPF}\left(105{ }^{\circ} \mathrm{C}, \pm 36\right.$ jam; kandungan air konstan $)$

b. Ukuran partikel OPF (250 mesh)

c. Konsentrasi Asam Sulfat 1\% (Katalis Organosolv pretreatment)

\subsubsection{Variabel Berubah}

- Organosolv pretreatment
a. Waktu Operasi $(60,120,180,240$ menit $)$
b. Konsentrasi Etanol $(35,55,75,90 \% \mathrm{v} / \mathrm{v})$
c. Temperatur $\left(100,120,150\right.$ dan $\left.180{ }^{\circ} \mathrm{C}\right)$

- Simultaneous Saccharification and Fermentation (SSF) Waktu Fermentasi (24, 36, 72 dan 96 jam)

\subsection{Prosedur Penelitian}

\subsubsection{Prosedur Pretreatment}

Tahap physical pretreatment OPF yang telah dikeringkan, selanjutnya dihancurkan dengan blender untuk mendapatkan ukuran bahan baku 250 mesh. OPF diayak untuk mendapatkan ukuran partikel 250 mesh. OPF yang telah ayak disimpan didalam desikator untuk mempertahankan level moisture. Tahap chemical pretreatment: Ditimbang OPF sebanyak massa gram tertentu, kemudian didelignifikasi dalam cairan pemasak (etanol) dengan variasi konsentrasi etanol, waktu dan temperatur yang telah ditentukan. Selanjutnya padatan (holoselulosa) dipisahkan dari cairan pemasak dengan menggunakan kertas saring. Padatan (holoselulosa) yang dihasilkan dicuci dengan air panas (Liquid hot water) hingga filtratnya jernih. Pulp (holoselulosa) yang telah dicuci selanjutnya dikeringkan didalam oven pada suhu $105^{\circ} \mathrm{C}$ sampai berat konstan ( \pm 24 jam $)$. 


\subsubsection{Prosedur Hidrolisis Enzimatis}

OPF yang telah dipretreatment atau tanpa pretreatment kemudian dihidrolisis. Sebanyak 3 gram substrat dan 60 $\mathrm{ml}$ natrium sitrat $0,05 \mathrm{M}$ sebagai buffer $(\mathrm{pH} 4,8)$ dicampur. Kemudian $0,5 \mathrm{~g} / \mathrm{l}$ antibacterial agent dan enzim hidrolitik ditambahkan ke campuran. Enzim mengandung 30 FPU selulase dan 60 IU $\beta$-glukosidase per gram substrat. Selanjutnya, labu atau Erlenmeyer ditutup dengan penyumbat karet butyl dan tutup aluminium dan diinkubasi selama 72 jam pada shaker incubator pada $45^{\circ} \mathrm{C}$ dan $120 \mathrm{rpm}$ [8]. Sampel cair diambil setiap waktu pada saat proses hidrolisis dan supernatant dipisahkan dari residu material padatan dengan sentrifugasi (3000 rpm selama 15 menit) dan disimpan pada $-20{ }^{\circ} \mathrm{C}$ sebelum analisa komposisi gula [9].

\subsubsection{Proses Simultaneous Saccharification and Fermentation (SSF)}

Etanol diproduksi dengan SSF pada suhu $37{ }^{\circ} \mathrm{C}$ dan $130 \mathrm{rpm}$ pada kondisi anaerobic selama waktu fermentasi yang divariasikan. Media mengandung $5 \mathrm{~g} / \mathrm{l}$ ekstrak yeast, 7,5g/l $\left(\mathrm{NH}_{4}\right)_{2} \mathrm{SO}_{4}, 0,75 \mathrm{~g} / 1 \mathrm{MgSO}_{4} .7 \mathrm{H}_{2} \mathrm{O}, 3,5 \mathrm{~g} / 1 \mathrm{~K}_{2} \mathrm{HPO}_{4}, 1 \mathrm{~g} / 1$ $\mathrm{CaCl}_{2} .2 \mathrm{H}_{2} \mathrm{O}$ dan $50 \mathrm{~g} / \mathrm{l}$ OPF pretreatment dan tanpa pretreatment yang dipreparasi dalam buffer sitrat $0,05 \mathrm{M} . \mathrm{pH}$ media diatur pada 5,5 dengan $\mathrm{NaOH} 1 \mathrm{M}$ [8]. Kemudian diautoclave pada $121^{\circ} \mathrm{C}$ selama 20 menit. Setelah didinginkan pada suhu kamar, $1 \mathrm{~g} / 1$ mikroorganisme dipersiapkan bersama dengan 20 FPU celulase dan 30 IU $\beta$-glukosidase per gram subtract dan ditambahkan $2.5 \mathrm{~g} / \mathrm{l}$ Tween 20. Produk fermentasi dianalisa yield etanol yang diperoleh [10].

\section{Hasil dan Pembahasan}

\subsection{Preparasi Bahan Biomassa Oil Palm Frond (OPF)}

Persiapan bahan baku bertujuan untuk mempermudah pada saat perlakukan proses, ukuran partikel yang kecil akan memudahkan proses karena memiliki luas permukaan yang besar. Pengecilan ukuan dilakukan dengan menggunakan alat penghancur yang kemudian dilakukan pengayakan. Pengayakan merupakan pemisahan berbagai campuran partikel padatan yang mempunyai berbagai ukuran bahan dengan menggunakan ayakan berukuran mesh. Ukuran partikel Oil Palm Frond (OPF) yang digunakan pada penelitian ini adalah 250 mesh.

\subsection{Analisa Kadar Air}

Penetapan kadar air pada pelepah kelapa sawit dilakukan dengan cara metode pengeringan atau metode oven selama 3 jam pada suhu $105{ }^{\circ} \mathrm{C}$. Sedangkan penetapan kadar abu dilakukan dengan menggunakan furnace yang dikerjakan pada suhu $210^{\circ} \mathrm{C}$. Kadar air dan kadar abu merupakan komposisi kimia yang harus diketahui didalam bahan pelepah kelapa sawit, karena kadar air dan kadar abu yang tinggi akan mempengaruhi tingginya keberadaan selulosa yang terkandung dibahan oil palm frond, pengurangan kadar air dan kadar abu pada berbagai variasi perlakukan seperti ditampilkan pada Gambar 1. berikut ini:

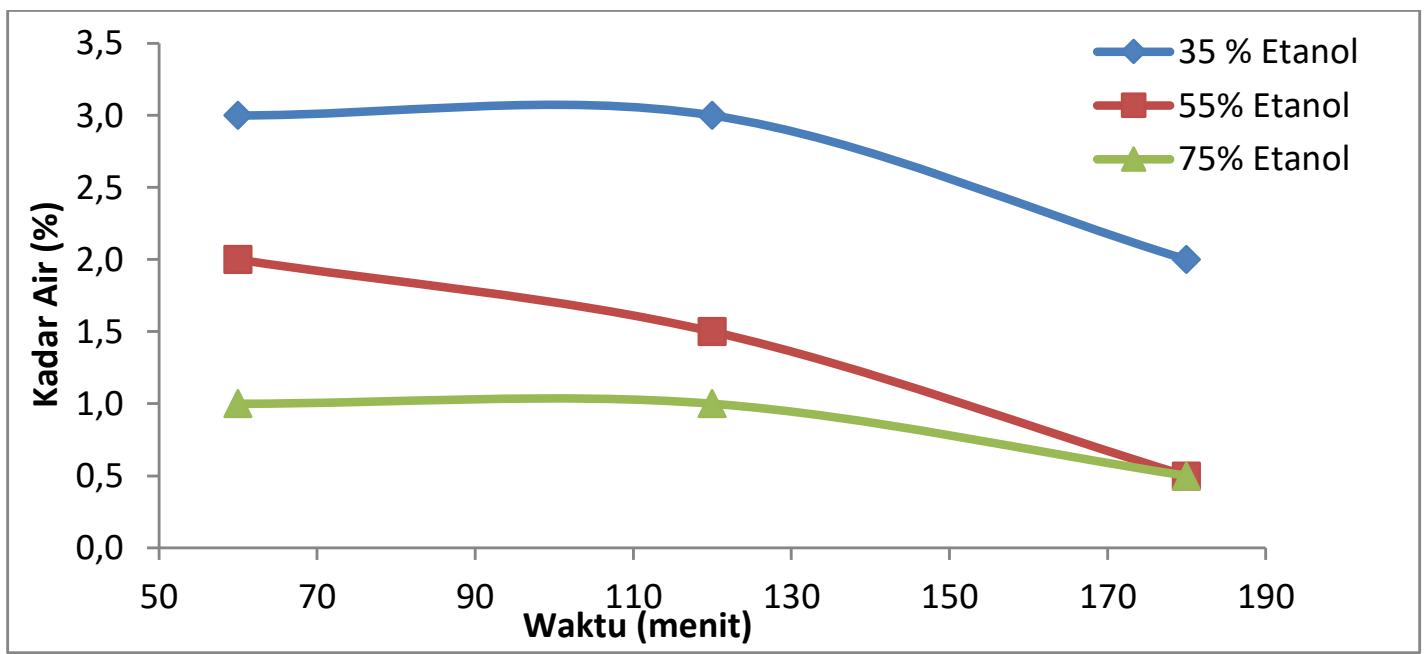

Gambar 1. Penetapan kadar air pada berbagai variasi perlakukan penelitian 
Berdasarkan penelitian yang telah dilakukan untuk analisa kadar air dimana variabel pemeriksaan dilakukan pada kondisi waktu 60, 120 dan 180 menit dengan variasi konsentrasi etanol yang dipakai sebagai pelarut yaitu $35 \%, 55$ $\%$ dan $75 \%$. Kondisi perlakukan dimana kadar air yang dihasilkan sesuai dengan variasi waktu semakin menurun. Hasil terbaik diperoleh pada waktu 180 menit dan kadar etanol $75 \%$.

\subsection{Analisa Kadar Abu}

Hasil analisa kadar abu dimana hasil yang terbaik juga diperoleh pada kondisi pelarut etanol $75 \%$. Pengaruh etanol yang digunakan sebagai pelarut pelepah sangat baik diperoleh pada kondisi tertinggi.

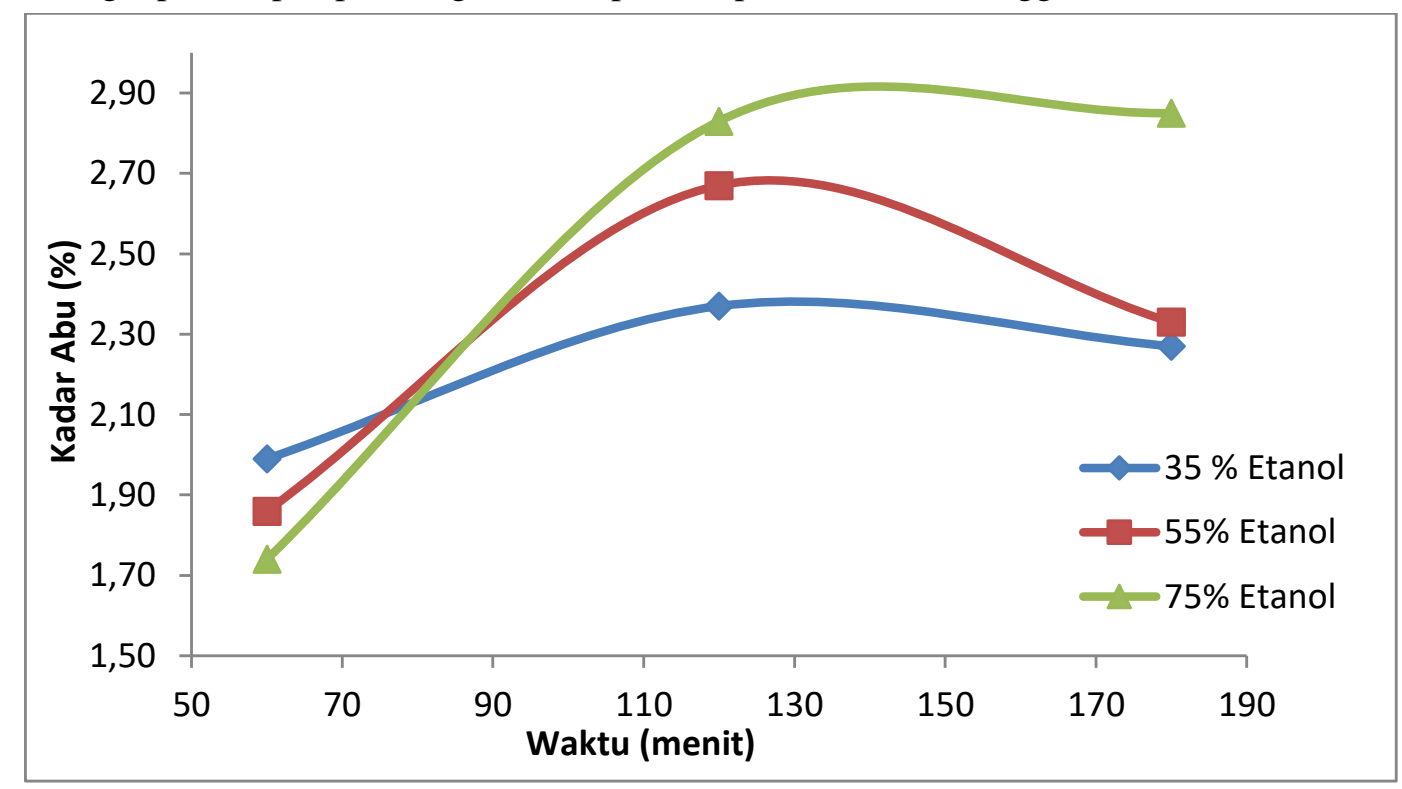

Gambar 2. Penetapan kadar air pada berbagai variasi perlakukan penelitian

\subsection{Perolehan Total Gula pada Tinjauan Proses Delignifikasi}

Bahan-bahan lignoselulosa umumnya terdiri dari sellulosa, hemiselulosa dan lignin. Ketiga komponen tersebut saling terikat kuat akibat dari struktur amorphous dan ikatan 1,4- $\beta$ pada selulosa, serta adanya senyawa lignin yang berperan sebagai senyawa yang melindungi selulosa dan hemiselulosa, senyawa inilah yang menyebabkan sulitnya terdegradasi selulosa dan hemiselulosa menjadi monomernya pada peristiwa hidrolisa, untuk itu dibutuhkan pretreatment untuk mengurangi senyawa lignin [11].

Dari hasil proses pretreatment (delignifikasi) terlihat adanya pengaruh konsentrasi larutan pemasak (etanol) terhadap perolehan total gula, seperti yang ditunjukkan pada Gambar 3. Perolehan total gula tertinggi adalah sebesar $34,09 \mathrm{mg} / \mathrm{L}$, diperoleh pada kondisi konsentrasi etanol 75\%. Peningkatan konsentrasi larutan pemasak (etanol) meningkatkan perolehan total gula. Dari Gambar 3. dapat dilihat peningkatan konsentrasi larutan pemasak (etanol) dari $35 \%$ sampai $75 \%$ meningkatkan yield total gula. 


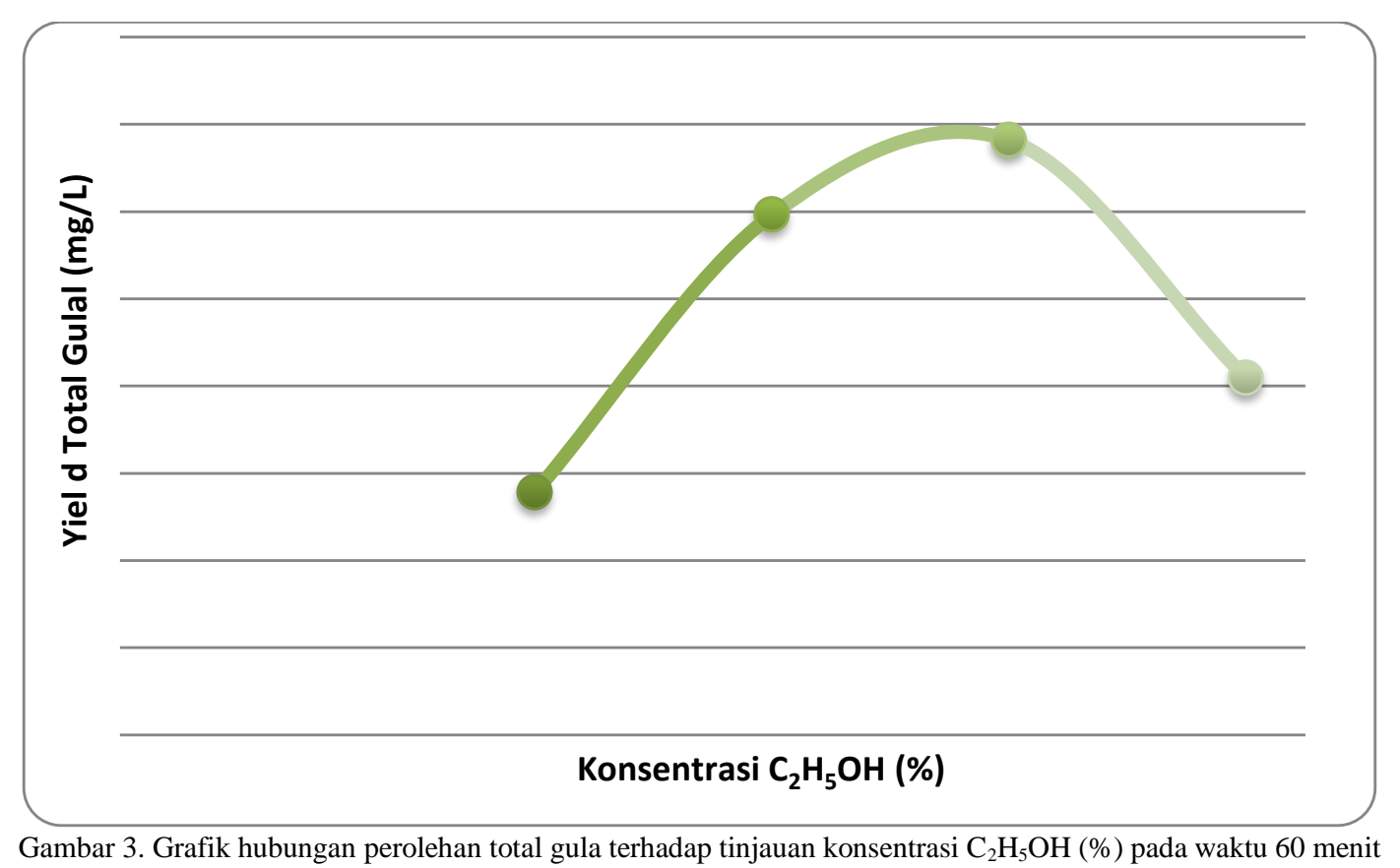

Kenaikan yield total gula tersebut juga berhubungan dengan bilangan kappa, seperti yang ditunjukkan pada Gambar 4., bilangan kappa menurun seiring peningkatan konsentrasi etanol. Penurunan bilangan kappa yang cukup signifikan terjadi pada konsentrasi etanol lebih besar dari 35\%. Penurunan bilangan Kappa menunjukkan semakin banyaknya lignin yang terurai, sehingga memudahkan degradasi holoselulosa menjadi gula pada proses hidrolisa.

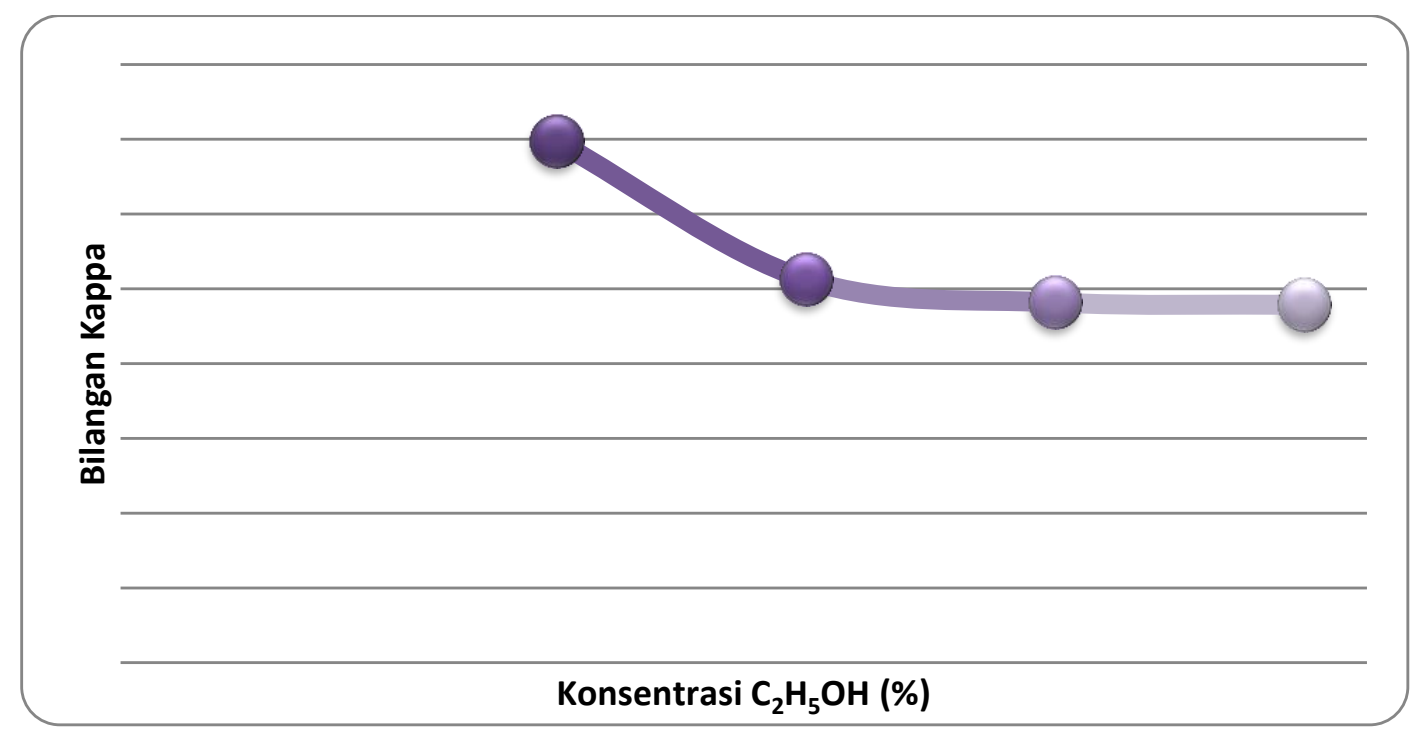

Gambar 3.4 Grafik hubungan bilangan kappa terhadap tinjauan pengaruh konsentrasi $\mathrm{C}_{2} \mathrm{H}_{5} \mathrm{OH}(\%)$ pada waktu 60 menit, katalis $\mathrm{H}_{2} \mathrm{SO}_{4} 1 \%$ dan suhu $100{ }^{\circ} \mathrm{C}$

Dari Gambar 4. juga terlihat penurunan yield total gula pada konsentrasi etanol lebih dari $75 \%$. Hal ini dikarenakan pada konsentrasi etanol yang terlalu tinggi dapat menyebabkan terjadinya reaksi etherifikasi antara selulosa dengan etanol membentuk eter, sehingga mengurangi kadar selulosa yang akan dihidrolisa [12].

Sedangkan menurut Rachmadiah [13], konsentrasi larutan pemasak etanol yang tinggi pada proses pretreatment juga dapat menguraikan beberapa hemiselulosa dalam larutan sehingga mengurangi kadar hemiselulosa untuk dihidrolisa, akibatnya perolehan yield total gula menurun [14]. 


\section{Kesimpulan}

Dari hasil penelitian yang telah dilakukan dengan kondisi proses yang telah diaplikasikan pada penelitian dapat diambil beberapa kesimpulan sebagai berikut:

1. Kondisi maksimum proses pretreatment diperoleh pada konsentrasi $\mathrm{C}_{2} \mathrm{H}_{5} \mathrm{OH} 75 \%$, temperatur $120{ }^{0} \mathrm{C}$ selama 60 menit tanpa menggunakan katalis $\mathrm{NaOH}$.

2. Kondisi maksimum pada proses hidrolisa diperoleh pada konsentrasi $\mathrm{H}_{2} \mathrm{SO}_{4} 0,5 \%$, temperatur $100{ }^{\circ} \mathrm{C}$ selama 45 menit.

3. Yield gula total tertinggi diperoleh pada kondisi delignifikasi dengan konsentrasi $\mathrm{C}_{2} \mathrm{H}_{5} \mathrm{OH} 75 \%$, temperatur 120 ${ }^{0} \mathrm{C}$ selama 60 menit tanpa menggunakan katalis $\mathrm{NaOH}$ dan kondisi hidrolisa $\mathrm{H}_{2} \mathrm{SO}_{4} 1 \%$, temperatur $90{ }^{0} \mathrm{C}$ selama 30 menit yaitu $93,25 \mathrm{mg} / \mathrm{L}$.

\section{Ucapan Terima Kasih}

Penulis mengucapkan terima kasih kepada Direktorat Riset dan Pengabdian Masyarakat, Kementerian Riset, Teknologi dan Pendidikan Tinggi yang telah memberikan bantuan dana Hibah Penelitian Kerjasama Perguruan Tinggi (PKPT) selanjutnya ucapan terima kasih kepada Universitas Syiah Kuala dan Universitas Serambi Mekkah Banda Aceh yang telah memberikan dukungan dan fasilitas sehingga tercapainya target penelitian ini.

\section{Referensi}

[1] Umar, Sayed, 2009. Potensi Perkebunan Kelapa Sawit Sebagai Pusat Pengembangan Sapi Potong Dalam Merevitalisasi Dan Mengakselerasi Pembangunan Peternakan Berkelanjutan. Pidato Pengukuhan Jabatan Guru Besar Tetap, Universitas Sumatera Utara, Medan.

[2] Hamid, Kamarul Azlan ABD, 2008. Production of Cellulose Fiber Oil Palm Frond Using Steam Explosion Method. Faculty of Chemical Engineering and Natural Resources, University of Malaysia, Pahang, pp. 18-24.

[3] Ishola, M., A. Jahandideh, B. Haidarian, T. Brandberg, M.J. Taherzadeh, 2013, Simultaneous Saccharification, Filtration And Fermentation (SSFF): A Novel Method For Bioethanol Production From Lignocellulosic Biomass. Bioresource Technology Journal Volume 133: 68-73.

[4] Swain, M.R. \& Krishnan, C., 2015. Improved Conversion Of Rice Straw To Ethanol And Xylitol By Combination Of Moderate Temperature Ammonia Pretreatment And Sequential Fermentation Using Candida Tropicalis. Industrial Crops and Products, 77, pp.10391046.

[5] Liu, Y.Y., Xu, J.L., Zhang, Y., Liang, C.Y., He, M.C., Yuan, Z.H. \& Xie, J., 2016. Reinforced Alkali-Pretreatment for Enhancing Enzymatic Hydrolysis of Sugarcane Bagasse. Fuel Processing Technology, 143, pp.1-6.

[6] Badan Pusat Statistik (BPS) Propinsi Aceh, Aceh Dalam Angka 2014.

[7] Yan, Fauzi, Ir., dkk., 2005. Kelapa Sawit (Edisi Revisi). Penerbit Penebar Swadaya, Bogor, pp. 142-158.

[8] Scully, S.M., and J. Orlygsson, 2014. Recent Advances in Second Generation Ethanol Production by Thermophilic Bacteria. Energies Journal, Volume 8 pp. 1-30.

[9] Osvaldo, Z. S., P. Putra S., M. Faisal, 2012. Pengaruh Konsentrasi Asam dan Waktu Pada Proses Hidrolisis dan Fermentasi Pembuatan Bioetanol dari Alang-Alang. Jurnal Teknik Kimia No.2 Vol. 18. pp 51-62.

[10] Wingren, A., Galbe, M. and Zacchi, G., 2003. Techno-Economic Evaluation of Producing Ethanol from Softwood: Comparison of SSF and SHF and Identification of Bottlenecks. Biotechnol. Progr. 19(4): 1109-1117.

[11] Orchidea., Rachmadiah, Lisa, Febriyanti S., dan Khoir, Lazuardi, 2009. Pengaruh Liquid Hot Water terhadap Perubahan Struktur Sel Bagas. Fakultas Teknik, Jurusan Teknik Kimia, ITS, pp-2-5.

[12] Sanchez, Oscar J., dan Carlos, Cardona A, 2008, Trends in Biotecnological Production of Fuel from different Feedstock, International Journal of Bioresource Technology, 99, pp. 5270-5295

[13] Rachmadiah, Orchidea., Andi, Krishnanta W., dan Dedi, Ricardo, 2009. Acid Hydrolysis Pretreatment of Bagasse-Lignocellulosic Material for Bioethanol Production, Fakultas Teknik, Jurusan Teknik Kimia, ITS, pp-1-9.

[14] Sun, Y., Cheng, J., 2002. 'Hydrolysis of Lignocellulosic Materials For Ethanol Production': A Review. Bioresource Technoogyl., 83, 1-11. 